\title{
Neurology 2004
}

\author{
Robert C. Griggs, MD, Editor-in-Chief; Kathleen M. Pieper, Online Managing Editor
}

Neurology continues to grow and develop-mirroring the growth and excitement of clinical neuroscience. The number of manuscripts received in 2003 increased by $6 \%$ over 2002 . Circulation increased by $7 \%$, the impact factor rose to 5.340 , and our international submissions have increased $3 \%$.

Online submission, peer review, and manuscript tracking. About 1 month after we launched the online submission system in February 2003, half of Neurology's submissions were still submitted via regular mail and half were uploaded electronically from authors. Now, only $8 \%$ come in via paper. The remainder are uploaded by authors and the response has been very positive. We continue to make changes and updates to the system to streamline the manuscript process and increase author and reviewer usability. Currently, the provider of this system has upgraded and configured their databases to provide increasing speed of the system. The online publisher will also provide hardware within the next year for authors to run their electronic figures through a preflight system that will indicate acceptability for publication.

Changes and new features for our readers and authors. Resident and Fellow Page. In this issue, there is an Editorial by Karen Johnston. ${ }^{1}$ Dr. Johnston is Program Director at the University of Virginia and Editor of Neurology's new Resident and Fellow Page. She has assembled an editorial team of residents and fellows to assist with this new section. It is a forum for residents and fellows to share their views on topics including teaching, ethics, practice, career choices, residency training, editorial, international education, research, historical, or opinion pieces. All articles will be peer-reviewed. We encourage submissions to the section and guidelines can be found in our Information for Authors. It is an onlineonly section and can be found at www.neurology.org by clicking on the link "Resident and Fellow Page." This month's Resident and Fellow Page will include articles from Drs. David Leach (ACGME executive director) and program directors Brett Kissela (University of Cincinnati) and Wendy Peltier (Medical College of Wisconsin), who will offer their perspectives on the initiation of the new resident duty hour standards.

Standards for Reporting of Diagnostic Accuracy (STARD) guidelines. Neurology now requires authors submitting studies of diagnostic accuracy to submit a checklist (for review purposes) and a flow diagram (for publication if article is accepted). ${ }^{2}$ This is a follow-up to the successful CONSORT statement that was instituted in 1996 and revised in 2001. The STARD initiative will enable authors to accurately describe the design, execution, analysis, interpretation, and implications of research on diagnostic tests. The goal of the STARD initiative is to improve the quality of reported studies and to standardize information flow to optimize the use of both established and novel diagnostic tests.

Publish ahead of print. We expect to begin posting articles ahead of print in mid-2004. About 25\% of content will be posted on the Web site before coming out in the print journal. We are still targeting to post content directly from the Neurology editorial office. When the print article appears, the online publish ahead of print article is replaced. Articles will be citable and indexed through Pub Med. The print journal will continue to be essential to readers for editorials, Highlights, and other similar material. Ultimately, all original articles will be posted online.

Patient Page. The online-only Patient Page continues to be Neurology's most accessed online section. We published a print editorial with a Patient Page in the November 25 issue to further draw the attention of print readers to this feature. ${ }^{3}$ The Patient Page is also getting extensive media attention including an article in the September 23 issue concerning menopause and memory. Most mention the Neurology Patient Page author by name and also provide a link to the Patient Page or the www.neurology.org homepage.

CME. Neurology's online-only CME is entering its fourth year. The October 14, 2003, print issue included an editorial by CME Editor, Dr. J. Clay Goodman. ${ }^{4}$ The editorial was accompanied by the issue's quiz and provided instructions to register and take online CME quizzes. We may do this once or twice a year in the print journal to educate our readership about the online CME.

Online access for developing countries. Through an initiative with the World Health Organization (WHO), Lippincott Williams \& Wilkins now offers free or deeply discounted online subscriptions to Neurology. The list of eligible countries is based on GNP per capita (World Bank figures, 1998). Institutions in countries with GNP per capita below $\$ 1,000$ are eligible for free access to the literature, whereas institutions in countries with GNP per capita between $\$ 1,000$ and $\$ 3,000$ may have access at reduced prices. Eligible institutions are medical, nursing, public

4 Copyright (C) 2004 by AAN Enterprises, Inc. 
health, and pharmacy schools; universities; health and medical research institutes; government offices working in the health sector; and medical libraries. To join, institutions need to complete an on-line HINARI registration form at http://www.healthinternetwork.org.

Correspondence. We have now integrated online and hard copy submission into one Correspondence section in both print and online. All Correspondence will now be handled through the Journal Web site only. It will not be handled by the online submission system. To submit Correspondence, access the specific article at www.neurology.org and "Send response to this article" in the content box at the top of the first page of the article. Authors of Correspondence will then be prompted to enter contact information and input and send the text of the letter. After review, letters (and author responses) will be posted rapidly. Selected accepted letters will be published in print as well. (For Correspondence submission, see www. neurology.org, Information for Authors.)

\section{References}

1. Johnston KC. Introducing the Resident and Fellow Page. Neurology $2004 ; 62: 12$.

2. Holloway R. Improving the flow of diagnostic information: the importance of STARD for authors and readers. Neurology 2003;61:600-601.

3. Jankowiak J, Brey RL. Are your patients getting the information they need? The Patient Page. Neurology 2003;61:1326-1327.

4. Goodman C. Neurology online CME: a quick study. Neurology 2003;61: $883-884$. 


\title{
Neurology
}

\author{
Neurology 2004 \\ Robert C. Griggs and Kathleen M. Pieper \\ Neurology 2004;62;4-5 \\ DOI 10.1212/WNL.62.1.4
}

\section{This information is current as of January 12, 2004}

\section{Updated Information \&} Services

References

Permissions \& Licensing

Reprints including high resolution figures, can be found at: http://n.neurology.org/content/62/1/4.full

This article cites 4 articles, 3 of which you can access for free at: http://n.neurology.org/content/62/1/4.full\#ref-list-1

Information about reproducing this article in parts (figures,tables) or in its entirety can be found online at:

http://www.neurology.org/about/about_the_journal\#permissions

Information about ordering reprints can be found online: http://n.neurology.org/subscribers/advertise

Neurology ${ }^{\circledR}$ is the official journal of the American Academy of Neurology. Published continuously since 1951, it is now a weekly with 48 issues per year. Copyright . All rights reserved. Print ISSN: 0028-3878. Online ISSN: 1526-632X.

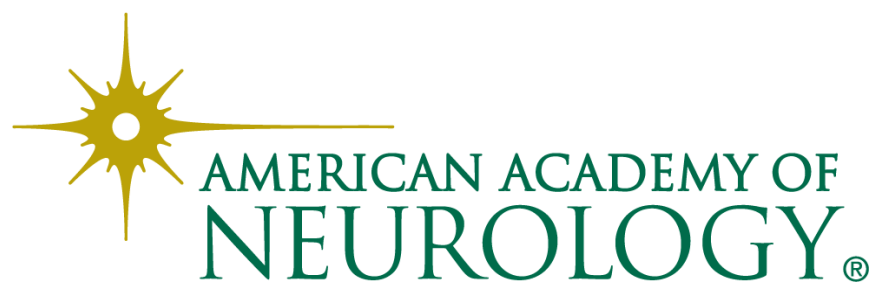

